\title{
Coral Reefs of the Perhentian Islands: Abundance Levels and Distribution Patterns of Hosting Sea Anemones, and Implications for Citizen-Science Monitoring.
}

Melissa Versteeg*, Alanah Campbell \& Hidayah Halid

Perhentian Marine Research Station, Pulau Perhentian, Terengganu, Malaysia

${ }^{*}$ Corresponding Author

Email: mversteeg5@gmail.com

\section{Abstract}

Around the Perhentian Islands, coral reefs have been undergoing significant degradation, as is reported annually through citizenscience coral reef monitoring programmes. Typical methodologies included in citizen-science surveys overlook the hosting sea anemones' contribution to lowered live coral cover (LCC) on reef sites. As sea anemones compete with corals for suitable substrate, nutrients, and light availability, the current study was designed to investigate hosting sea anemone abundance and distribution patterns independently. In addition to identifying and assessing sites of localised sea anemone dominance, sea anemones were examined to identify factors that positively influence reproductive success and growth rate, including formations, hosting status, and resident Amphiprion species. In total, 379 sea anemone samples were analysed over $1600 \mathrm{~m} 2$ of Perhentian reef, making this study the first known independent investigation into sea anemone abundance patterns around the Perhentian Islands. Statistical analysis revealed that at site Village Reef, sea anemone abundance was higher than would be expected in healthy reef settings, and sea anemone cover was negatively impacting LCC. At second research site Teluk Keke, such analysis resulted in marginally insignificant results, potentially due to temporal onset differences or pressures exerted by other coral competitors. The most dominant sea anemone species, Heteractis magnifica $(\mathrm{N}=352)$, was analysed to test whether factors linked to higher reproductive success and growth rate were present in larger sea anemones. Results corroborate that larger sea anemones were significantly more likely to be actively hosting and were more often encountered in cluster formations. The current study employed a citizen-science method to explore its feasibility as a survey tool to identify reef sites undergoing dominance shifts, such as could be further developed and incorporated into currently used citizen-science monitoring programmes. 
bioRxiv preprint doi: https://doi.org/10.1101/2021.01.22.427756; this version posted January 22, 2021. The copyright holder for this preprint (which was not certified by peer review) is the author/funder, who has granted bioRxiv a license to display the preprint in perpetuity. It is made available under aCC-BY 4.0 International license.

\section{Introduction}

On the Perhentian reefs, coral abundance and health has been subject to degradation as is demonstrated by a steady decrease of live coral cover (LCC) on longitudinally assessed sites ${ }^{[1-13]}$. In 2017, reef assessments conducted by the Perhentian Marine Research Station revealed a bleaker reef health status than had been held previously (data available on request due to permit restrictions ${ }^{\star *}$ ) Analysis of 41 unique sites around the Perhentian Islands indicated a live coral cover average of just $27 \%$ (sd=14) compared to an LCC of $42.32 \%$ as reported by other citizen-science reef monitoring programmes ${ }^{[11\}}$. Although differences in results are partly attributable to discrepancies in methodology, the lower LCC estimate puts Perhentian coral reefs right on the edge of a reef degradation classification from 'fair' to 'poor'.

For the most part, monitoring of coral reefs around the Perhentian Islands has been completed using citizen-science methodologies and trained volunteers ${ }^{[3]}$. Such approaches to local reef monitoring have proven very effective in collecting relevant data, which is subsequently used to analyse trends and inform protective regulations ${ }^{[14]}$. More so, these approaches provide sufficient statistical power to identify site integrity profile discrepancies, which are instrumental to effective marine park zone designation ${ }^{[15] .}$

As a key determinant of citizen-science based reef surveys, various bio-indicators are measured to record and analyse ongoing trends ${ }^{[1-13]}$. Methods generally include a holistic selection of variables which are relatively easy to work with. Furthermore, citizenscience reef monitoring approaches often assess relevant variables together with other correlated determinants. Although these methods are low cost and easy to implement, they may fail to spot underlying competition dynamics on the reefs, increasing the likelihood for misinterpretation, misinformation and ill-informed management ${ }^{16]}$.

One practise in citizen-science reef monitoring prone to inaccurate representation involves nutrient indicator algae (NIA) recordings as an assessment of coral competition. The underlying premise of this method involves recording macroalgae abundance to indirectly measure dissolved nutrient levels, which negatively impact coral survival[17]. However, as Littler and Littler ${ }^{[18]}$ explain, using algae presence to pinpoint eutrophication effects can be flawed. High macroalgal abundance does not directly indicate an elevated level of nutrients dissolved into the water body, as macroalgae species can thrive independent of nutrient levels. More so, not all types of nutrient indicator algae found on the reef detract from coral growth, and whilst this understanding is widely shared (for example, coralline crustose algae is often categorised separately), citizen-science methodologies often collate distinct variables into ambiguously defined groups ${ }^{[19]}$. Subsequently, insight into underlying drivers and practical implication values related to these results is limited. In identifying this inherently ambiguous practise alternative assessment approaches should be investigated, so as to increase the accuracy with which we can identify and understand ongoing reef competition dynamics.

A marine species that has been ubiquitously linked to elevated dissolved nutrient levels regards sea anemones ${ }^{[20]}$. Additionally, higher competitive pressure is exerted by sea anemones on sites where live coral is present. In conditions of high dissolved nutrient levels and live coral cover, anemone growth rates are higher, and their competitive strategies more aggressive than in conditions with 
bioRxiv preprint doi: https://doi.org/10.1101/2021.01.22.427756; this version posted January 22, 2021. The copyright holder for this preprint (which was not certified by peer review) is the author/funder, who has granted bioRxiv a license to display the preprint in perpetuity. It is made available under aCC-BY 4.0 International license.

no live coral cover [21]. Currently, the relationship between sea anemone abundance and live coral cover is not receiving the attention warranted by scientific finding attesting to the direct competition between sea anemones and corals. Regarding Malaysia's coral ecosystems in general, and the Perhentian Islands' reefs specifically, no distinct investigations into sea anemone abundance and their effects on live coral cover are occurring at this point.

Perhentian Island site assessment methods commonly used currently include sea anemones only in combination with tunicate, hydroid, and corallimorph presence in a category labelled 'Other'[13]. In collectively recording the presence of these marine organisms, the opportunity to recognise independent effects attributable to individual competitor species are lost. Regarding sea anemones, their independent coral competition is scientifically demonstrated, with increased anemone abundance negatively influencing coral planula recruitment and thus negatively impacting coral recovery[22]. This finding highlights the potential in studying sea anemone abundance as a means to also study variables concerning coral presence on the reef. Furthermore, categorizing species within a broad class increases the likelihood for observers to miss individually attributable effects; a cognitive bias known as the Von Restorff effect[23]. Such an observer bias could help explain why no previous independent assessment of anemones has been completed as a part of citizen-science reef assessments pertaining to the Perhentian Islands.

Sea anemones are direct coral competitors, and their elevated presence has been reported in outbreaks on newly colonised reefs following collapse events ${ }^{[24]}$. Sea anemone abundance and substrate cover is positively influenced by dissolved nutrient levels ${ }^{[25]}$, with suitable environments allowing anemone aggregation into extensive anemone beds ${ }^{[26]}$. In favourable settings, anemones can directly outcompete stony corals for attachment substrates ${ }^{[27]}$. Givensea anemones' longevity, their potential for year-round asexual reproduction ${ }^{[27-29]}$, and their fast rate of growth in conducive conditions, high anemone abundance can be an indication of reef ecosystem dominance transition. Moreover, examining anemone density levels offers a means to investigate and monitor eutrophication effects, given anemones' ability to thrive under conditions of high nutrient levels ${ }^{[17,20] .}$

Sea anemones are invertebrate marine animals of approximately $1000+$ different species worldwide. Like corals, sea anemones have strict environmental requirements due to their dependency on algal symbionts ${ }^{[30]}$ and thus are only found in the photic zone. They have tentacles with nematocysts for defence, plankton capture, and opportunistic predation ${ }^{[28}$. Sea anemones require specific elements for growth, including ammonia, nitrogen and sulfur. They acquire the bulk of their nutritional needs through zooxanthellic photosynthetic symbionts, but also possess a capacity for nutrient absorption from the water column through skin tissue. More so, actively hosting sea anemones recycle nutrients from waste excreted by symbiont fish[30-31]. In fact, sea anemones that successfully host ectosymbionts such as anemonefish are shown to also host greater concentrations of zooxanthellae, positively affecting acquired energy and growth rates ${ }^{[31]}$. The plethora of mechanisms through which anemones can obtain nutrients, speaks to a competitive edge and increased resistance in the face of environmental changes.

Only 10 actinian species have evolved to host symbiotic anemonefish (Amphiprions), of which there are 28 known species. Papua New Guinea is the only location where all 10 species of anemones with hosting capacity can be seen ${ }^{[28]}$. For the rest of the Indo-West Pacific, numbers of hosting anemone species tend to be about half, including the Perhentian Islands where hosting anemone species 
bioRxiv preprint doi: https://doi.org/10.1101/2021.01.22.427756; this version posted January 22, 2021. The copyright holder for this preprint (which was not certified by peer review) is the author/funder, who has granted bioRxiv a license to display the preprint in perpetuity. It is made available under aCC-BY 4.0 International license.

Heteractis magnificus, Heteractis crispa, Entacmaea quadricolor, Stichodactyla gigantea, Stichodactyla haddoni and Stichodactyla mertensii are encountered. An important factor influencing anemone abundance regards hosting status. When anemones are actively hosting, growth rates increase threefold [29]. In fact, Holbrook \& Schmitt's research revealed that actively hosting anemones have significantly higher asexual reproductive rates.

Another advantage culminating from the obligatory symbiosis between anemones and their symbiotic fish regards increased oxygenation of actively hosting anemones during the night. Szczebak et al. investigated adaptive behaviours of Amphiprion species during nighttime when paired with hosting anemones ${ }^{[2]}$. Results show that anemonefish influence oxygen levels of the host anemones by altering flow rates around the anemone host's tissues, leading to increased oxygen availability and absorption, subsequently increasing metabolic rates. These findings further demonstrate mechanisms by which anemones use multiple adaptive strategies favourable to survival under changing environmental demands.

The current study set out to measure anemone abundance at Perhentian reef sites that show indicators of heightened concentrations of anemones. One of these sites is 'Village Reef', a location which the local community also informally refers to as 'Nemo', in acknowledgement of its high abundance of anemones and anemonefish. The second site included in the study was a reef area called 'Teluk Keke', which is a highly prized site due to its diverse coral presence. We aim to investigate sea anemone abundance levels to localise sites of high sea anemone concentrations, which subsequently identifies sites where sea anemones are successfully outcompeting live corals. More so, the highly prevalent Heteractis magnifica sea anemones were examined to identify markers of successful survival, including size estimates, hosting status, and formation classification. Previous studies have already demonstrated that hosting sea anemones more frequently engage in asexual reproduction, a reproductive strategy assumed to underlie the formation of sea anemone beds ${ }^{[29,33]}$. Assessing whether these relevant factors are found in the sea anemones around the Perhentian reef sites can inform distribution trends, and could thus aid the development of appropriate management strategies.

The sea anemones assessment used in the current study is novel to any citizen-science based reef monitoring program employed around the Perhentian reefs. Through the identification of anemone-dominated reef sites, and showing that high sea anemone cover impedes live coral cover, we demonstrate a prominent role for hosting sea anemones in coral reef assessments. We thus propose the inclusion of sea anemone abundance surveying as a valid means by which to monitor anemone-coral competition on the reefs of the Perhentians. In addition, sea anemone monitoring can indirectly identify changes in sedimentation levels, as well as point out increased levels of dissolved nutrients which also inhibit coral reef recovery.

\section{Materials and Methods}

Data was collected at research sites Village Reef (central coordinates: 553’39.05”N, 10243’37.61”E) and Teluk Keke (central coordinates: $\left.5^{\circ} 53^{\prime} 14.0316^{\prime \prime} \mathrm{N}, 102^{\circ} 44^{\prime} 20.9004^{\prime \prime E}\right)$. Village Reef lies on the intertidal zone off the South-East of Perhentian Kecil, and is 
bioRxiv preprint doi: https://doi.org/10.1101/2021.01.22,427756; this version posted January 22,2021 . The copyright holder for this preprint (which was not certified by peer review) is the author/funder, who has granted bioRxiv a license to display the preprint in perpetuity. It is made available under aCC-BY 4.0 International license.

also locally referred to as Village Beach due to its proximity to local village 'Kampung Pasir Hantu' (Figure 1a). Teluk Keke (Figure $1 \mathrm{~b})$ is located to the West of Perhentian Besar, and its reef contains rocky reef areas in combination with sheltered regions of shallow reef. Between May and August 2020, SCUBA technique was deployed to study the anemones within the research sites. In addition, live coral cover estimates were collected using point intercept readings along the same transect line. At site regions too shallow for SCUBA (depth $<2.0 \mathrm{~m}$ ), data was collected using freediving. All data collection sessions took place between $8.30 \mathrm{am}$ and $11.59 \mathrm{am}$ and visibility during data collection sessions had to be over five meters as a prerequisite to diving. All statistical analyses were run using 'R: A language and environment for statistical computing'[34].

At Village Reef, several hosting sea anemone species can be identified, including Stichodactyla gigantea, Stichodactyla mertensii, Stichodactyla haddoni, Entacmaea quadricolor, Heteractis crispa and most notably Heteractis magnifica. Stichodactyla mertensii, Heteractis crispa, and Entacmaea quadricolor were located outside the survey boundary, and Stichodactyla gigantea was found only in shallower regions of the survey site. As for Teluk Keke, three species of anemone were recorded; Heteractis magnifica, Entacmaea quadricolor, and Stichodactyla mertensii. At Teluk Keke Heteractis magnifica also demonstrated a disproportionately large abundance. To avoid loss of statistical power due to differences in growth rates, expansion patterns and formations ${ }^{[28,35]}$, all data pertaining to Heteractis magnifica was extracted for analysis of successful survival markers.

Within the boundaries of survey area Village Reef, a total of fourteen 20 meter transects were laid out in parallel using a $225^{\circ}$ South West bearing, as well as spatially referencing from a stable landmark. Shallow transects not including any sea anemones were excluded on the premise that these areas did not meet habitat requirements. As for the survey site Teluk Keke, ten 20 meter transects were laid out in parallel, using a $270^{\circ}$ North West bearing. At Teluk Keke, a partially exposed rock made for a natural landmark for additional spatial referencing.

Distance between parallel transects was set at 4 meters, so as to allow full surveyance of the site whilst mitigating overestimation due to overlap. Following the laying of the transect, two research divers regressed along the transect, taking a two meter width perpendicular to the transect line, and recorded data for all encountered sea anemones. To record live coral cover, the substrate cover directly underneath the same transect line was visually identified at $50 \mathrm{~cm}$ intervals, at a total of 40 points per transect line ${ }^{[36]}$. Hard and soft coral data points were subsequently calculated to produce a LCC percentage estimate per transect line. An interobserver analysis revealed an overall recording and identification accuracy of $96,7 \%$. 
bioRxiv preprint doi: https://doi.org/101101/2021.01.22.427756; this version posted January 22,2021 . The copyright holder for this preprint (which was not certified by peer review) is the author/funder, who has granted bioRxiv a license to display the preprint in perpetuity. It is made available under aCC-BY 4.0 International license.

Figure 1. Satellite image of site Village Reef, at Pulau Perhentian Kecil (a) and Teluk Keke on Pulau Perhentian Besar (b), with photographic depiction of typical sea anemone abundance.

Note. (1a) Yellow lines indicate transect lengths, each 20 meters long with the jetty functioning as the starting point for each transect. Image source: Google 2020, CNES/Airbus. Photograph credits: Alanah Campbell.

Note. (1b) Red lines indicate transect lengths, each 20 meters long with the rock acting as a natural referencing point. Image source: Google 2020, CNES/Airbus. Photograph credits: Alanah Campbell. 
Upon identifying a sea anemone specimen, a long and short axis measurement of the oral disc was taken using a tailor's tape and relevant spatial mapping measures were recorded. In addition, sea anemone species identification was made, its formation was

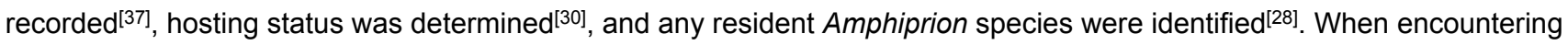
ambiguity, video footage was collected to allow cross referencing ex situ. In classifying clusters of anemones, specimens were included within a cluster when a fully expanded individual's tentacles could touch a neighbouring sea anemone.

As formulas to calculate area coverage assume full coverage between the elliptical long and short axis ${ }^{[38]}$, clusters which did not fully cover the substrate, or clusters which did not assume an elliptical shape, were adjusted for by recording the area cover estimate (0$100 \%)$. Furthermore, site rugosity measurements were taken to convert cover estimates accordingly. When calculating area cover percentages of the sampled sea anemones, adjusted coverage estimates were divided by transect segment area, which was calculated at $20 \mathrm{~m}^{2}$ excluding reefscape adjustments (4 meter width $\times 5$ meter length intervals along the 20 meter transect line, for a total area per transect of $80 \mathrm{~m}^{2}$ ). To establish a baseline reading on sea anemone percentage presence in healthy coral reef areas, transect lines were laid on site areas with high live coral cover (criteria: $L C C<60 \%, L_{\text {mean }}=67.5 \%$ ) and anemone coverage was calculated using the same methodology as previously described. The average sea anemone cover percentage was subsequently taken to estimate expected sea anemone abundance at coral reef sites of good health. 
bioRxiv preprint doi: https://doi.org/10.1101/2021.01.22 427756; this version posted January 22,2021 . The copyright holder for this preprint (which was not certified by peer review) is the author/funder, who has granted bioRxiv a license to display the preprint in perpetuity. It is made available under aCC-BY 4.0 International license.

\section{Results}

At Village Reef, a total of 203 sea anemone samples were identified and analysed. Heteractis magnifica was the most dominant species, with $98.03 \%$ presence $(\mathrm{N}=199)$. Furthermore, two specimens of Stichodactyla gigantea were identified, and just two Stichodactyla mertensii specimens were recorded (Table 2 and Figure 2). The average size of the studied anemones was $0.126 \mathrm{~m}^{2}$ $\left(\mathrm{sd}=0.165 \mathrm{~m}^{2}, \max =1.300 \mathrm{~m}^{2}, \min =0.003 \mathrm{~m}^{2}\right)$, and $73.40 \%$ were actively hosting Amphiprion spp. at the time of analysis $(\mathrm{N}=149)$. Of the hosting anemones, $89.26 \%$ hosted Amphiprion ocellaris symbionts $(\mathrm{N}=133)$, and $10.74 \%$ were found to host Amphiprion perideraion $(\mathrm{N}=16)$. As for formations (Figure $5 \mathrm{~b}), 49.26 \%$ included solitary anemones $(\mathrm{N}=100) .30 .54 \%$ were clustered in groups of 5 or less $(\mathrm{N}=62), 12.81 \%$ were clustered in groups of 5 to 10 individuals $(\mathrm{N}=26), 2.96 \%$ were part of clusters of $10-15$ individuals $(\mathrm{N}=6)$, and the remaining $4.43 \%$ of sea anemones were part of groups comprising $16-30$ individuals $(\mathrm{N}=9)$. The total estimated area cover of sea anemones at Village Reef was $25.487 \mathrm{~m}^{2}$.

At Teluk Keke, a total of 176 sea anemones formations were identified and analysed. Of the total sample, Heteractis magnifica was also the most dominant species, with $86.93 \%$ presence $(\mathrm{N}=153)$. Entacmaea quadricolor species were identified at $11.93 \%(\mathrm{~N}=21)$ and just 1 specimen of Stichodactyla mertensii was recorded (Table 2 and Figure 2), representing $0.57 \%$. The average size of the studied sea anemones at Teluk Keke was $0.043 \mathrm{~m}^{2}\left(\mathrm{sd}=0.027 \mathrm{~m}^{2}, \max =0.161 \mathrm{~m}^{2}, \mathrm{~min}=0.005 \mathrm{~m}^{2}\right)$, and $88.64 \%$ were actively hosting Amphiprions at the time of analysis $(\mathrm{N}=156)$. Of the hosting anemones, $76,92 \%$ hosted Amphiprion ocellaris symbionts $(\mathrm{N}=120)$, and $10.26 \%$ were found to host Amphiprion perideraion ( $\mathrm{N}=16)$. Furthermore, Amphiprion frenatus was found to reside on $8.97 \%$ of actively hosting sea anemones $(\mathrm{N}=14)$ and one anemone was recorded actively hosting Amphiprion clarkii, with a percentage representation of $0.64 \%$. As for formations (Figure $5 b$ ), sea anemones at Teluk Keke were found only in solitary formations or in clusters including less than 5 individuals. $85,80 \%$ were of solitary formations $(N=151)$, with the remaining $14.20 \%$ clustered in groups of less than $5(\mathrm{~N}=25)$. The total sea anemone area cover at Teluk Keke was $7.623 \mathrm{~m}^{2}$.

At Village Reef, sea anemone abundance at the survey site was skewed, with decreased sea anemone coverage in shallower areas. The average percentage cover of anemones was $12.74 \%(\min =0.28 \%$, max $=44.78 \%)$ per $20 \mathrm{~m}^{2}$, with an average live coral cover of $38.83 \%(\min =15.38 \%, \max =60.0 \%)$. Table 1 displays all sea anemone coverage results and LCC estimates for the survey sites. Results show a higher percentage of anemone cover within the first, and thus deepest parts of the analysed site, coinciding with lower LCC percentages at Village Reef, whilst the highest anemone coverage estimates at Teluk Keke were localised around the centre of the survey site. The average live coral cover at Teluk Keke was only $20.00 \%$. with an average anemone cover of $3.81 \%$. Analysis of sea anemone cover at reef sites found to be in a good health state (LCC $<50 \%$, according to Reef Check Malaysia) revealed a percentage presence of $2.43 \%$ on coral dominated sites. Both at Village Reef and Teluk Keke, sea anemone coverage was found to be elevated as compared to sea anemone coverage found in sites of 'good' health as indicated by live coral cover estimates surpassing $50 \%$. 
Table 1. Recorded area cover and percentage cover for analysed sea anemones, in addition to LCC percentages at survey sites Village Reef and Teluk Keke, per analysed transect.

Note. Analysis of sea anemone coverage on site areas assessed to be in 'Good' coral health (LCC $<50 \%$ ), revealed an average sea anemone area coverage of $1.984 \mathrm{~m}^{2}$ per $80 \mathrm{~m}^{2}$ or $2.43 \%$

Table 2. List of sea anemone species found at survey sites Village Reef and Teluk Keke, including tentacle identification details.

Note. Stichodactyla haddoni and Heteractis crispa were not located within the survey area parameters.

Figure 2. Bar graph displaying sea anemone species distributions recorded at Village Reef $(\mathrm{N}=203)$ and Teluk Keke ( $N=176)$.

Figure 3. Bar graph displaying sea anemone cover and live coral cover (LCC) per $80 \mathrm{~m}^{2}$, for Village Reef and Teluk Keke.

To test whether anemone presence directly impacts the presence of live corals, anemone cover and live coral cover were analysed using linear regression modelling (Figure 3 and Figure 4). Results reveal that at Village Reef, sea anemone cover significantly predicts live coral cover $(F(1,8)=6.486, p<0.05)$, with higher levels of sea anemone abundance predicting lower levels of live coral cover $\left(r=-0.669, R^{2}=0.447, \mathrm{se}=0.271\right)$. As for Teluk Keke, no significant results were found when analysing sea anemone and live coral cover levels $\left(F(1,8)=5.494 * 10^{-5}, p=0.994\right.$, se $\left.=0.886\right)$. 
Figure 4. Scatterplot displaying the relationship between sea anemone cover and live coral cover (LCC) at Village Reef (a) and Teluk Keke (b).

Note. (a) Site Village Reef. $R^{2}=0.44$, $L C C=-0.693 x+47.5, p<0.05, r=0.690$ and (b) Site Teluk Keke. $R^{2}=0.001$, LCC $=0.66 x+19.7$, n.s.

As an indicator of survival and reproductive success ${ }^{[29]}$, the sampled Heteractis magnifica anemones were tested to determine whether actively hosting specimens are significantly larger than their non-hosting counterparts (Figure 5a). A non-parametric MannWhitney $U$ test was used to test a significant difference in size between the actively hosting and non-hosting groups. Results revealed a significant difference in sea anemone size at Village Reef $(U=1214, p<0.001)$, where actively hosting sea anemones are larger than non-actively hosting sea anemones $\left(X_{\text {hosting }}=0.158 m^{2}, X_{\text {non-hosting }}=0.039 m^{2}\right)$. The Mann-Whitney $U$ test for survey site Teluk Keke also revealed a significant difference in size between active and non-active hosting status of Heteractis magnifica $(U=575, p<0.001)$, with larger sizes recorded for hosting specimens $\left(X_{\text {hosting }}=0.045 \mathrm{~m}^{2}, X_{\text {non-hosting }}=0.026 \mathrm{~m}^{2}\right)$

A further indicator of survival rate and reproductive success relates to anemones' asexual reproductive levels. With increased asexual reproduction, anemones are predicted to occur in cluster formations more often ${ }^{[27,29]}$. A Chi-Square test was utilised to test the relationship between hosting status and cluster formations. Results demonstrate that actively hosting anemones were more often encountered in clusters than their non-hosting counterparts at Village Reef $\left(X^{2}(1)=20.688, p<0.001\right)$ (Figure 5b). Results for Teluk Keke were marginally non-significant $\left(X^{2}(1)=3.7953, p=0.0514\right)$. 
bioRxiv preprint doi: https://doi.org/10.1101/2021.01.22 427756; this version posted January 22,2021 . The copyright holder for this preprint (which was not certified by peer review) is the author/funder, who has granted bioRxiv a license to display the preprint in perpetuity. It is made available under aCC-BY 4.0 International license.

Figure 5. Bar graphs illustrating Heteractis magnifica hosting status in relation to (a) average size $\left(\mathrm{m}^{2}\right)$ and $(\mathrm{b})$ formation at Village Reef and Teluk Keke.

Note. Heteractis magnifica specimens sampled at Village Reef, N=194 and Teluk Keke, N=153.

\section{Discussion}

The purpose of the current study was to identify distribution patterns and species abundance levels of sea anemones at survey sites Village Reef and Teluk Keke. Sea anemone coverage estimates were subsequently analysed to determine whether higher anemone levels are directly impacting live coral cover (LCC) locally, and to relate sea anemone cover to a baseline estimate such as would be expected for intact coral reef sites. This study also sought to locally examine variables which influence sea anemone growth and reproductive success, including hosting status and formations, which have been demonstrated to positively impact sea anemones' competitive success ${ }^{[27,29,33]}$. More so, we set out to demonstrate feasibility of utilising sea anemones abundance monitoring as a survey tool appropriate for citizen-science reef monitoring with which to investigate sea anemone cover and success and its competition to live corals on the Perhentian coral reefs.

Results indicate that higher abundance of sea anemones negatively impact live coral cover (LCC) on reefs. Since sea anemones and corals require similar substrate, nutrient, and light penetration requirements ${ }^{[20,22,25]}$, they are in direct competition for available resources. Although this relationship was not significant for Teluk Keke, the high presence of algae on that survey site (mean NIA= $42 \%, \min =25 \%, \max =57.5 \%$ ), may explain the lack of power to identify the relationship between sea anemone presence and LCC levels. The recorded sea anemone abundance levels at Teluk Keke do exceed levels expected in healthy coral reef settings. Further monitoring and assessment should examine whether Teluk Keke is undergoing a similar phase shift as is occuring at Village Reef, with differences in temporal onset, or different patterns related to pressures exerted by high macroalgae abundance.

Comparing LCC percentages for the survey sites and the islands' average demonstrates that the LCC percentage for Village Reef is above the islands' average, even if just slightly (Mean $\mathrm{LCC}_{\text {Village Reef } 2020}=38,83 \%$; Mean $\left.\mathrm{LCC}_{\text {Perhentian Islands } 2019}=35,50 \%\right)^{[13]}$. Finding both higher LCC levels and higher sea anemone abundance levels is unsurprising given that sea anemone dominance co-depends on the presence of live coral ${ }^{[21]}$. It would be interesting to study whether this relationship entails a threshold, or tipping point in terms of LCC estimates and the ability of sea anemones to take over aggressively. At survey site Village Reef, sea anemones seem to have the upper hand in the matter, with significantly higher sea anemone coverage estimates in the deeper regions of the site.

The rate of success with which sea anemones can outcompete competitors is influenced by factors such as hosting status, cluster formations, and nutrient availability[25,31]. The presence of resident Amphiprion species, for example, can positively affect sea anemones' growth rates ${ }^{[29]}$. Analysis of data collected at both research sites confirms that the majority of sampled sea anemones exhibit factors associated with higher reproductive success, and that sampled species exhibiting these factors are significantly larger. This result implies the need to continue to monitor these areas to examine temporal changes in abundance levels and future 
bioRxiv preprint doi: https://doi.org/10.1101/2021.01.22.427756; this version posted January 22, 2021. The copyright holder for this preprint (which was not certified by peer review) is the author/funder, who has granted bioRxiv a license to display the preprint in perpetuity. It is made available under aCC-BY 4.0 International license.

distribution patterns, with the expectation to find higher growth rates for sea anemones that are exhibiting success-associated factors. More so, efforts should be poured into the investigation of the individual contributions of these factors on sea anemone growth rates, so that expected growth can be calculated accurately for future scenarios. Such mechanistic insight can be used to further shape accurate sea anemone survey methodologies fit for citizen-science programmes, in addition to informing effective management strategies with continued sea anemone growth on the reefs.

The high homogeneity of the analysed anemone specimens and symbiotic Amphiprion species was striking: At Village Reef $98 \%$ of sampled anemones were Heteractis magnifica, and $89 \%$ of identified anemonefish species were A. ocellaris. At Teluk Keke these values were $87 \%$ and $77 \%$ respectively. Given this finding, it stands to reason that identification of Perhentian reef habitats with high concentrations of Heteractis magnifica or A. ocellaris could provide a simple yet effective preliminary tool to locate areas potentially affected by extensive coral collapse, lowered biodiversity, and decreased carrying capacity. Longitudinal assessment of these sites over time could reveal which Perhentian sites are undergoing profound and undesired phase shifts. These results could subsequently aid biodiversity management and the identification of habitats unsuited to coral restoration efforts as high sea anemone abundance patterns indicate coral stressors such as increased sedimentation and higher levels of dissolved nutrients. Future resources should be allocated to further develop a sea anemone survey tool within citizen-science approaches to reef assessments of the Perhentians, where cover and abundance measurements can be used to estimate whether a site has passed the threshold of coral dominance. The current study demonstrates the wider value of exploring sea anemone monitoring for all Malaysian reef monitoring programmes, as clusters of sea anemones are found throughout the Malaysian marine systems, but are often excluded from scientific study[26,33].

To better estimate sea anemone abundance patterns outside of the citizen-science monitoring approach, water quality testing should be incorporated in all studies on sea anemone blooms. In doing so, fluctuations of dissolved nutrient levels can be investigated and related to ongoing sea anemone dynamics. For the Perhentian Islands specifically, the presence of a waste water outlet in close proximity to the research site (Figure 1a) shows the potential for nutrient offloading into the water, which has been established as a factor impacting both sea anemone abundance, and live coral cover ${ }^{[17,21]}$. A further area in need of more study involves sedimentation. Prior research indicates that sea anemones can outcompete corals in the face of increased sedimentation levels ${ }^{[20]}$. More so, experiments conducted by Nugues $\&$ Roberts ${ }^{[39]}$ suggest that the direct impact of algae on coral mortality is negligible when compared to the mortality effect sedimentation has on smothering corals, highlighting the potential for sedimentation to work along two independent mechanisms when it comes to decreased coral dominance on the reefs. With climate change increasing rain events and thus the introduction of organic sedimentation into the water bodies surrounding the islands, in addition to increases in tourism [40] with subsequent increases in coastal development and land run-off, such research is very relevant to the Perhentian Islands. Assessment of sea anemone abundance in relation to dissolved nutrient parameters, sedimentation levels and waste water outlet proximity would be a valuable next phase in sea anemone research.

The used methodologies in this study were shaped by restraints in resources and site habitat idiosyncrasies. As such oral disc recordings were taken to estimate coverage for all species of sea anemones. Due to diurnal changes in sea anemone expansions of the oral disc, measurements of the pedal disc diameter (PDD) is generally more accurate and thus preferred ${ }^{[35]}$. However, the reef 
rugosity at Teluk Keke made PDD measurement collection unfavourable. Furthermore, all data was collected using visual sensus and assessor accuracy training. This technique was selected as it mimics the citizen-science approaches used in other reef assessments. Nonetheless, this technique is more prone to inaccuracies due to observer effects, and ideally should be examined in parallel to techniques with higher accuracy such as photo identification. An analysis of several data collection techniques would help investigate the accuracy levels obtained when using an approach suited to citizen-science monitoring, and could thus determine whether such a monitoring tool offers substantial value and information for sea anemone research.

\section{Conclusion}

The current study set out to better understand complex reef dominance and outbreak dynamics for the Perhentian Island by monitoring sea anemone-coral competition with a research approach suitable to citizen-science monitoring programmes. Results demonstrated highly localised abundance patterns of sea anemones which were directly impacting live coral cover. In addition, examined sea anemones displayed variables indicative of increased growth rates and reproductive success, and specimens displaying such factors were indeed significantly larger. Identifying and monitoring sea anemone abundance around the Perhentian Islands as a citizen-science approach offers a valuable tool with which to reveal sites of lowered ecosystem integrity, potentially high dissolved nutrient abundance and sedimentation levels, undesired dominance shifts and their combined negative impacts on corals. Further researching localised sea anemone outbreaks could prove instrumental in informing conservation strategies for stable coral recovery on these reefs, and thus several future research directions are proposed to continue sea anemone assessments for the Perhentian Islands . 
bioRxiv preprint doi: https://doi.org/101101/2021.01.22.427756; this version posted January 22,2021 . The copyright holder for this preprint (which was not certified by peer review) is the author/funder, who has granted bioRxiv a license to display the preprint in perpetuity. It is made available under aCC-BY 4.0 International license.

\section{Acknowledgements}

This research and its resultant report was produced with the support of Perhentian Marine Research Station. Many thanks to the team, and specifically to Ecoteer Cofounder Daniel Quilter. The data collection was conducted at reef sites Village Reef and Teluk Keke (Pulau Perhentian Kecil and Besar, respectively) with the Coral Rehabilitation Project in Perhentian Island permit JTLM 6104/1/1 Jld 3 (28) and the Strategic Partnership: Reef Care Program permit Prk. ML. 610-3/1 (9), both issued by Malaysian Marine Parks Department Taman Laut Malaysia (http://marinepark.dof.gov.my). The current research was carried out with aims of informing rehabilitation prospects through habitat composition surveys, in addition to establishing baseline monitoring data on site dynamics. A big thank you is also due to everyone who supported the research dives by donating to the fundraiser. Terima kasih banyak! 
bioRxiv preprint doi: https://doi.org/101101/2021.01.22.427756; this version posted January 22,2021 . The copyright holder for this preprint (which was not certified by peer review) is the author/funder, who has granted bioRxiv a license to display the preprint in perpetuity. It is made available under aCC-BY 4.0 International license.

\section{References}

1. Reef Check Malaysia. 2007 Annual Survey Report [Internet]:25 pages. Available from:

https://static1.squarespace.com/static/5c9c815e348cd94acf3b352e/t/5e2724378ecda6054e753719/1579623503322/RCMSUR+2007 .pdf

2. Reef Check Malaysia. Reef Check Malaysia Coral Reef Monitoring Report 2008 [Internet]:30 pages. Available from: https://static1.squarespace.com/static/5c9c815e348cd94acf3b352e/t/5e272416c179bf7b311363b0/1579623454468/RCMSUR+2008. pdf

3. Reef Check Malaysia. Status of Coral Reefs in Malaysia 2009 [Internet]:44 pages. Available from: https://static1.squarespace.com/static/5c9c815e348cd94acf3b352e/t/5e2723cf3f5cf3703bd65bf5/1579623417862/RCMSUR+2009.p df

4. Reef Check Malaysia. Reef Check Malaysia Annual Survey Report 2010 [Internet]:44 pages. Available from: https://static1.squarespace.com/static/5c9c815e348cd94acf3b352e/t/5e27238ccc229c6d83af33da/1579623348093/RCMSUR+2010. $\underline{\mathrm{pdf}}$

5. Reef Check Malaysia. Status of Coral Reefs in Malaysia, 2011 [Internet]:37 pages. Available from: https://static1.squarespace.com/static/5c9c815e348cd94acf3b352e/t/5e272353cc229c6d83af29ef/1579623285798/RCMSUR+2011. pdf

6. Reef Check Malaysia. Status of Coral Reefs in Malaysia, 2012 [Internet]:61 pages. Available from: https://static1.squarespace.com/static/5c9c815e348cd94acf3b352e/t/5e27230a6a01722e910a2098/1579623197707/RCMSUR+2012 $\underline{\mathrm{pdf}}$

7. Reef Check Malaysia. Status of Coral Reefs in Malaysia, 2013 [Internet]:67 pages. Available from: https://static1.squarespace.com/static/5c9c815e348cd94acf3b352e/t/5e2722c989aaea52421b9363/1579623120789/RCMSUR+2013 .pdf

8. Reef Check Malaysia. Status of Coral Reefs in Malaysia, 2014 [Internet]:73 pages. Available from: https://static1.squarespace.com/static/5c9c815e348cd94acf3b352e/t/5e2722663ce1e84bb6b5bcf1/1579623037099/RCMSUR+2014. $\underline{\mathrm{pdf}}$

9. Reef Check Malaysia. Status of Coral Reefs in Malaysia, 2015 [Internet]:95 pages. Available from: https://static1.squarespace.com/static/5c9c815e348cd94acf3b352e/t/5d03584dfbd7100001ea15b3/1560500326832/2015+Annual+S urvey+Report.pdf

10. Reef Check Malaysia. Status of Coral Reefs in Malaysia, 2016 [Internet]:92 pages. Available from: https://static1.squarespace.com/static/5c9c815e348cd94acf3b352e/t/5d035875fbd7100001ea1714/1560500363157/2016+Annual+S urvey+Report.pdf

11. Reef Check Malaysia. Status of Coral Reefs in Malaysia, 2017 [Internet]:98 pages. Available from: https://static1.squarespace.com/static/5c9c815e348cd94acf3b352e/t/5d0358913864a6000181d6ce/1560500399102/2017+Annual+S urvey+Report.pdf

12. Reef Check Malaysia. Status of Coral Reefs in Malaysia, 2018 [Internet]:94 pages. Available from: https://static1.squarespace.com/static/5c9c815e348cd94acf3b352e/t/5d0358b672408300016b83e3/1560500436686/2018+Annual+S urvey+Report.pdf

13. Reef Check Malaysia. Status of Coral Reefs in Malaysia, 2019 [Internet]:87 pages. Available from:

https://static1.squarespace.com/static/5c9c815e348cd94acf3b352e/t/5e4e461750bc066ba303bbc5/1582188086832/2019+Annual+S urvey+Report.pdf

14. Hodgson G, Stepath CM. Using Reef Check for long-term coral reef monitoring in Hawaii. J. E. Maragos and R. GroberDunsmore, eds. Proc. Hawaii Coral. 1999;173-184.

15. Lau CM, Kee-Alfian AA, Affendi YA, Hyde J, Chelliah A, Leong YS, Low YL, Yusop PAM, Leong VT, Halimi AM, Shahir YM, Ramdhan RM, Lim AGL, Zainal NI. Tracing Coral Reefs: A Citizen Science Approach in Mapping Coral Reefs to Enhance Marine Park Management Strategies. Front. Mar. Sci. 2019;6:539.

16. Hunter J, Alabri A, van Ingen C. Assessing the quality and trustworthiness of citizen science data. Concurrency Computat.:Pract. Exper. 2013; 25:454-466. 
bioRxiv preprint doi: https://doi.org/10.1101/2021.01.22.427756; this version posted January 22, 2021. The copyright holder for this preprint (which was not certified by peer review) is the author/funder, who has granted bioRxiv a license to display the preprint in perpetuity. It is made available under aCC-BY 4.0 International license.

17. D'Angelo C, Wiedenmann J. Impacts of nutrient enrichment on coral reefs: new perspectives and implications for coastal management and reef survival. Curr. Opin. Environ. Sustain. 2014;7:82-93.

18. Littler MM, Littler DS. The nature of macroalgae and their interactions on the reefs. Smithson. Contrib. Mar. Sci. 2013;39:187198.

19. Harris JL. The Ecology of Turf Algae on Coral Reefs. Dissertation on the internet, UC San Diego. 2015. Available from https://escholarship.org/uc/item/7gb5h3zm

20. Liu P-J, Hsin M-C, Huang Y-H, Fan T-Y, Meng P-J, Lu C-C, Lin H-J. Nutrient enrichment coupled with sedimentation favors sea anemones over corals. PLoS One. 2015;10(4):e0125175.

21. Liu P-J, Lin S-M, Fan T-Y, Meng P-J, Shao K-T, Lin H-J. Rates of overgrowth by macroalgae and attack by sea anemones are greater for live coral than dead coral under conditions of nutrient enrichment. Limnol. Oceanogr.. 2009;54(4):1167-1175.

22. Chen CA, Dai C-F. Local phase shift from Acropora-dominant to Condylactis-dominant community in the Tiao-Shi Reef, Kenting National Park, southern Taiwan. Coral Reefs. 2004;23:508

23. Wallace WP. Review of the historical, empirical, and theoretical status of the von Restorff phenomenon. Psychol. Bull. 1965;63(6):410-424. Available from: https://doi.org/10.1037/h0022001.

24. Tkachenko KS, Wu B-J, Fang L-S, Fan T-Y. Dynamics of a coral reef community after mass mortality of branching Acropora corals and an outbreak of anemones. Mar. Biol. 2007;151:185-194.

25. Kuguru BL, Mgaya YD, Ohnman MC, Wagner GM. The reef environment and competitive success in the Corallimorpharia. Mar. Biol. 2004;145:875-884.

26. Ridzwan AR. Recovery processes of coral communities following the crown-of-thorns starfish, Acanthaster planci, infestations of the east coast islands of Peninsular Malaysia. Dissertation, University of Newcastle upon Tyne. 1993.

27. Chadwick-Furman NE, Spiegel M. Abundance and clonal replication in the tropical corallimorpharian Rhodactis rhodostoma. Invertebr. Biol. 2000;119(4):351-360.

28. Fautin DG, Allen GR. Field Guide to Anemonefishes and Their Host Sea Anemones. Converted for electronic publication by Humpries J, Sherman D; The MUSE project. Perth: Western Australian Museum;1992.

29. Holbrook SJ, Schmitt RJ. Growth, reproduction and survival of a tropical sea anemone (Actiniaria): benefits of hosting anemonefish. Coral Reefs. 2005;24:67-73.

30. Fautin DG. The anemonefish symbiosis: what is known and what is not. Symbiosis. 1991;10:23-46.

31. Roopin M, Chadwick NE. Benefits to host sea anemones from ammonia contributions of resident anemonefish. J. Exp. Mar. Biol Ecol. 2009;370:27-34.

32. Szczebak JT, Henry RP, Al-Horani FA, Chadwick NE. Anemonefish oxygenate their anemone hosts at night. J. Exp. Biol. 2013;216:970-976.

33. Brolund TM, Tychsen A, Nielsen LE, Arvedlund M. An assemblage of the host anemone Heteractis magnifica in the northern Red Sea, and distribution of the resident anemonefish. J. Mar. Biol. Ass. U.K. 2004;84:671-674.

34. RStudio Team. Rstudio: Integrated Development for R. Version 4.0.1.[software]. RStudio. 2020 [cited 09-05-2020; downloaded 06-06-2020]. Available from: http://www.rstudio.com/

35. Dunn DF. Dynamics of external brooding in sea anemone Eptictic Epiactis prolifera. Mar. Biol. 1977;39:41-49.

36. Manuputty Djuwariah AEW. Method Guide: Point Intercept transect (PIT) for Community, Baseline Study and Coral Health Monitoring at Marine No Take Zone Area (DPL). Coral Reef Rehabilitation and Management Program, Indonesian Institute of Sciences. Jakarta, Indonesia; 2009.

37. Allen GR. Anemonefishes and their amazing partnership. Australian Natural History. 1975;18(8):274-277.

38. Hirose Y. Habitat, distribution and abundance of coral reef sea-anemones (Actiniidae and Stichodactylidae) in Sesoko Island Okinawa, with notes on expansion and contraction behavior. Galaxea, JCRS. 1985;4:113-127.

39. Nugues MM, Roberts CM. Coral mortality and interaction with algae in relation to sedimentation. Coral Reefs. 2003;22:507-516. 
bioRxiv preprint doi: https://doi.org/10.1101/2021.01.22.427756; this version posted January 22,2021 . The copyright holder for this preprint (which was not certified by peer review) is the author/funder, who has granted bioRxiv a license to display the preprint in perpetuity. It is made available under aCC-BY 4.0 International license.

40. Taman Laut Malaysia. Data Pelawat Dari Tahun 2000 Hingga 2016 [internet]. Available from:

http://marinepark.dof.gov.my/files/TOTAL\%20OF\%20VISITORS\%20IN\%20MARINE\%20PARK\%20FROM\%20YEAR\%202000\%20T O\%20YEAR\%202016.pdf

**The data presented in this study are available upon request from the corresponding author*. The data are not publicly available due to legal publishing constraints as defined in the regulations inherent to the permits issued by Taman Laut Malaysia. 


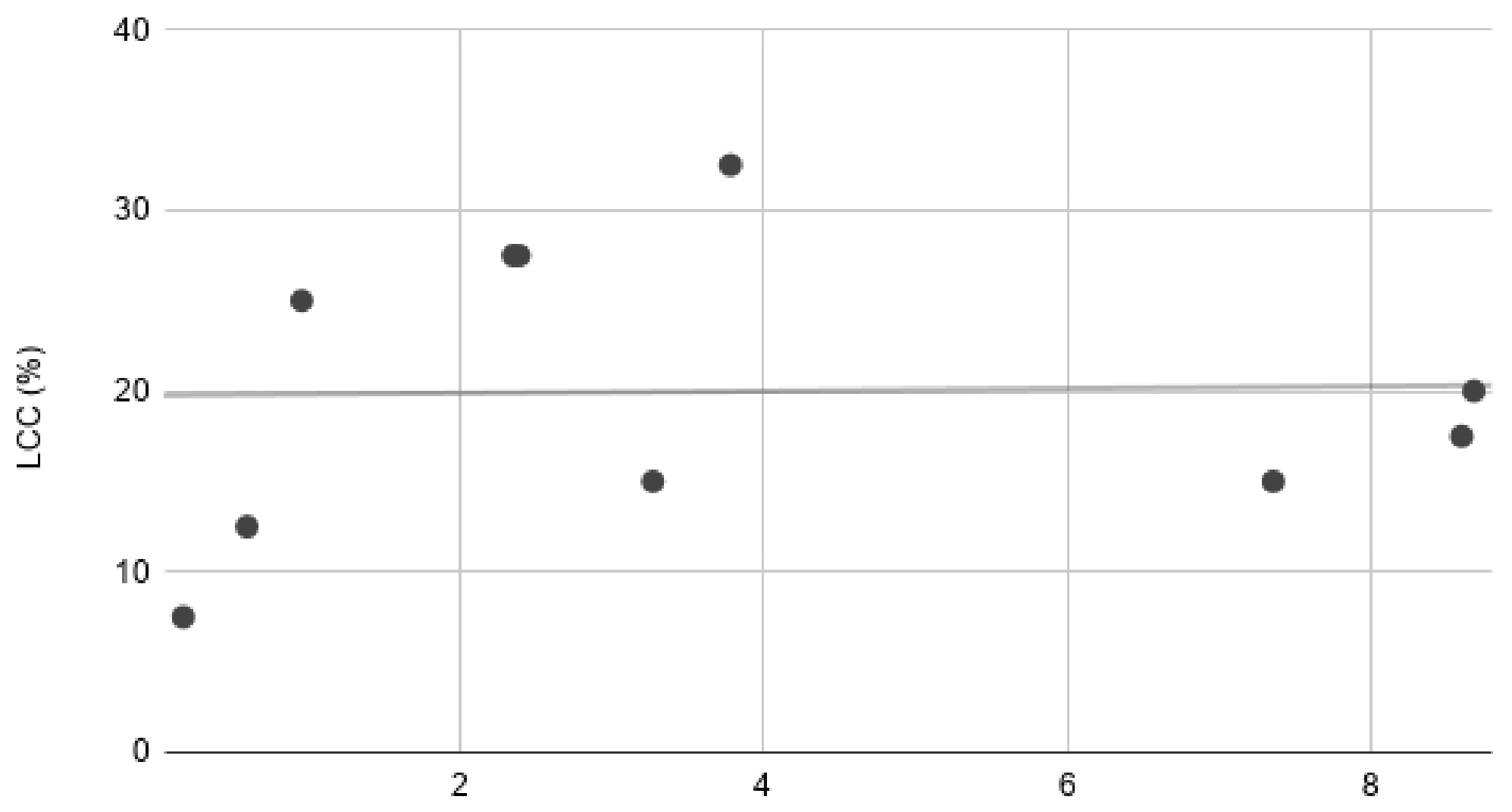

Sea Anemone Cover (\%)

Figure 4. Scatterplot displaying the relation 


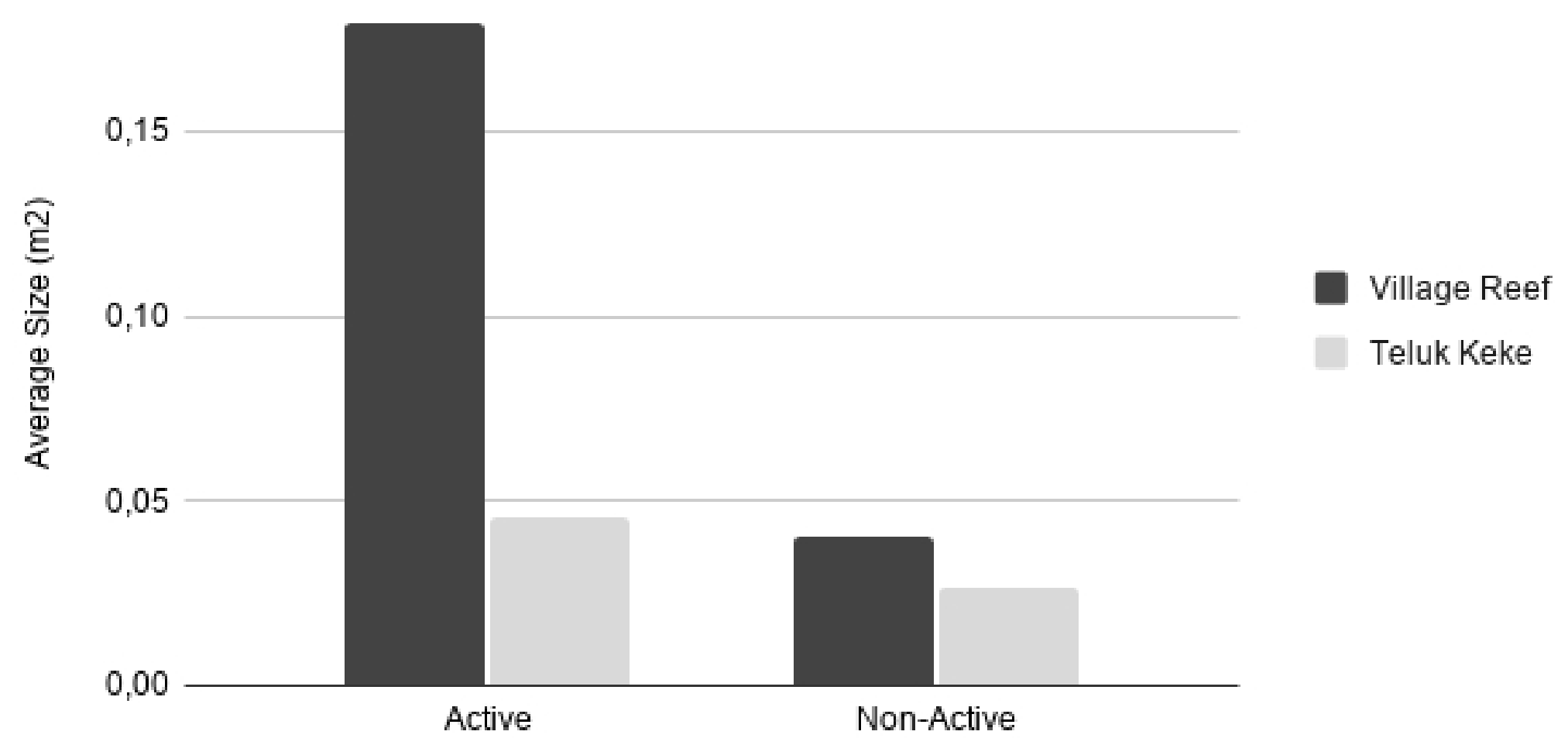

Hosting Status

Figure 5. Bar graphs illustrating Heteractis 


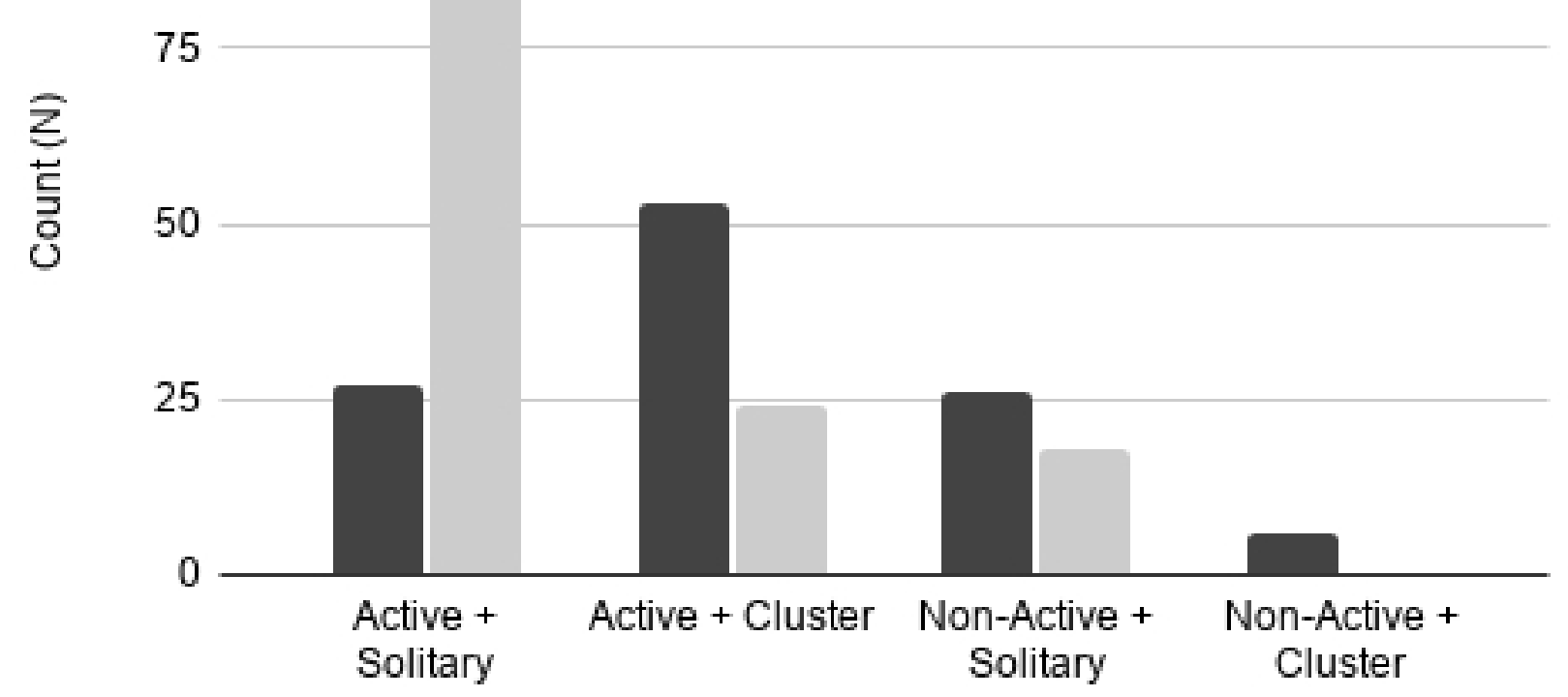

Hosting Status and Formation

Figure 5. Bar graphs illustrating Heteractis 


\begin{tabular}{|c|c|c|c|c|c|c|c|c|}
\hline & \multicolumn{6}{|c|}{ Sea Anemones } & \multicolumn{2}{|c|}{ Live Coral Cover (LCC) } \\
\hline & \multicolumn{3}{|c|}{ Village Reef } & \multicolumn{3}{|c|}{ Teluk Keke } & \multirow{2}{*}{$\begin{array}{l}\begin{array}{l}\text { Village } \\
\text { Reef }\end{array} \\
\begin{array}{l}\text { Cover } \\
(\%)\end{array}\end{array}$} & \multirow{2}{*}{$\begin{array}{l}\text { Teluk Keke } \\
\begin{array}{l}\text { Cover } \\
\text { (\%) }\end{array}\end{array}$} \\
\hline $\begin{array}{l}\text { Transect } \\
\text { (T) }\end{array}$ & $\begin{array}{c}N \\
\text { (clusters) }\end{array}$ & $\begin{array}{c}\text { Area } \\
\text { cover } \\
\left(m^{2}\right)\end{array}$ & $\begin{array}{c}\text { Cover } \\
\text { (\%) }\end{array}$ & $\begin{array}{c}N \\
\text { (clusters) }\end{array}$ & $\begin{array}{c}\text { Area } \\
\text { cover } \\
\left(\mathrm{m}^{2}\right)\end{array}$ & $\begin{array}{l}\text { Cover } \\
\text { (\%) }\end{array}$ & & \\
\hline 1 & 54 & 6.646 & 33.23 & 1 & 0.036 & 0.18 & 15.38 & 7.50 \\
\hline 2 & 58 & 8.958 & 44.79 & 3 & 0.192 & 0.96 & 36.84 & 25.00 \\
\hline 3 & 44 & 5.333 & 26.67 & 13 & 1.477 & 2.39 & 17.50 & 27.50 \\
\hline 4 & 21 & 2.814 & 14.07 & 19 & 0.653 & 3.27 & 17.50 & 15.00 \\
\hline 5 & 11 & 0.795 & 3.98 & 39 & 1.717 & 8.59 & 35.90 & 17.50 \\
\hline $\begin{array}{l}\text { print doi: hitps: } \\
\text { likt was not ce }\end{array}$ & $\begin{array}{l}\mathrm{rg} / 10.1101 / 2021.0 \\
\text { d.py peer review) } \\
\text { rpetuity. It is made }\end{array}$ & 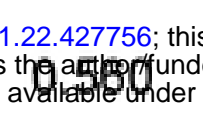 & 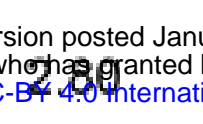 & $\begin{array}{l}\text { 22, 2021. The } \\
\text { lif glicense to } \\
\text { license. }\end{array}$ & $\begin{array}{l}\text { right holder for this } \\
\text { laythe preprint in }\end{array}$ & 7.35 & 45.00 & 15.00 \\
\hline 7 & 2 & 0.232 & 1.16 & 37 & 1.734 & 8.67 & 47.50 & 20.00 \\
\hline 8 & 1 & 0.076 & 0.38 & 17 & 0.755 & 3.78 & 60.00 & 32.50 \\
\hline 9 & 1 & 0.100 & 0.50 & 11 & 0.470 & 2.35 & 60.00 & 27.50 \\
\hline 10 & 4 & 0.227 & 1.14 & 1 & 0.119 & 0.60 & 50.00 & 12.50 \\
\hline
\end{tabular}

\section{Table 1. Recorded area cover and percentage cover for analy}




\begin{tabular}{llll}
\hline Common name & Scientific name & $N$ & Photo of tentacle detail \\
\hline $\begin{array}{llll}\text { Magnificent Sea } \\
\text { Anemone }\end{array}$ & $\begin{array}{l}\text { Heteractis } \\
\text { magnifica }\end{array}$ & $\begin{array}{l}\mathrm{N}=199 \\
\text { Teluk Keke, } \\
\mathrm{N}=153\end{array}$ \\
\hline
\end{tabular}

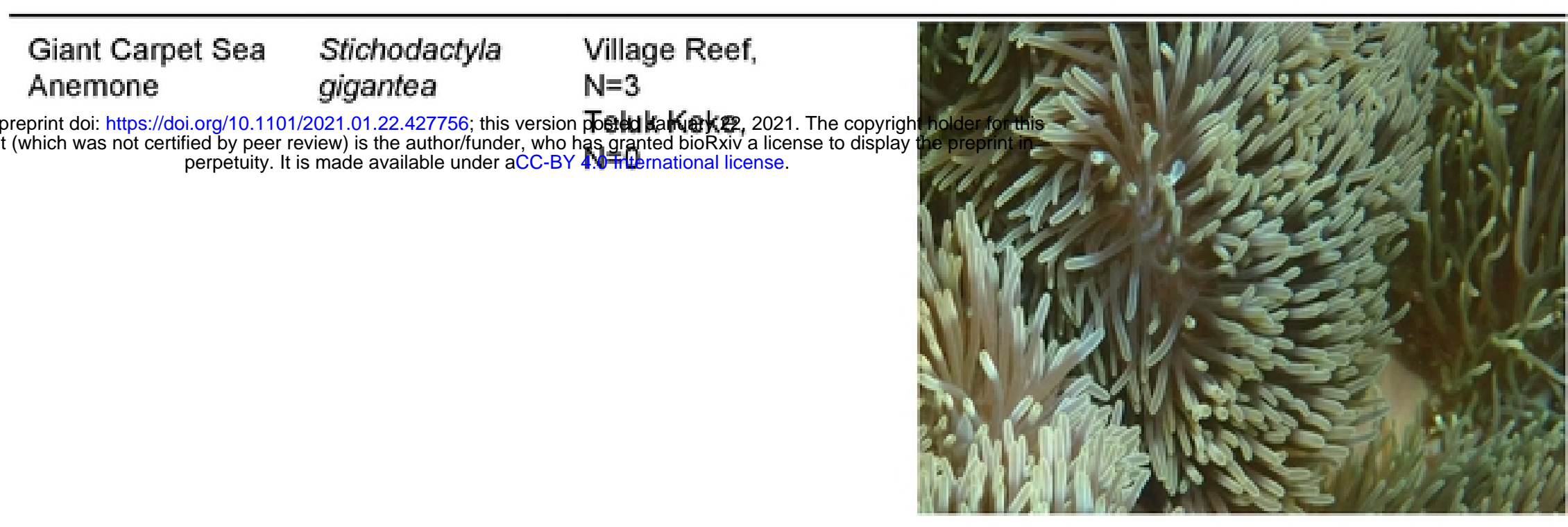

\begin{tabular}{|c|c|c|}
\hline $\begin{array}{l}\text { Merten's Carpet } \\
\text { Sea Anemone }\end{array}$ & $\begin{array}{l}\text { Stichodactyla } \\
\text { mertensii }\end{array}$ & $\begin{array}{l}\text { Village Reef, } \\
\mathrm{N}=2 \\
\text { Teluk Keke, } \\
\mathrm{N}=1\end{array}$ \\
\hline
\end{tabular}

\begin{tabular}{llll}
\hline $\begin{array}{l}\text { Bubble Tentacle } \\
\text { Sea Anemone }\end{array}$ & $\begin{array}{l}\text { Entacmaea } \\
\text { quadricolor }\end{array}$ & $\begin{array}{l}\text { Village Reef, } \\
\mathrm{N}=0 \\
\text { Teluk Keke, } \\
\mathrm{N}=21\end{array}$ \\
\end{tabular}

\section{Table 2. List of sea anemone species found at survey sites Vil}




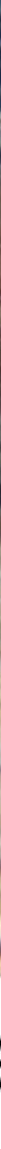




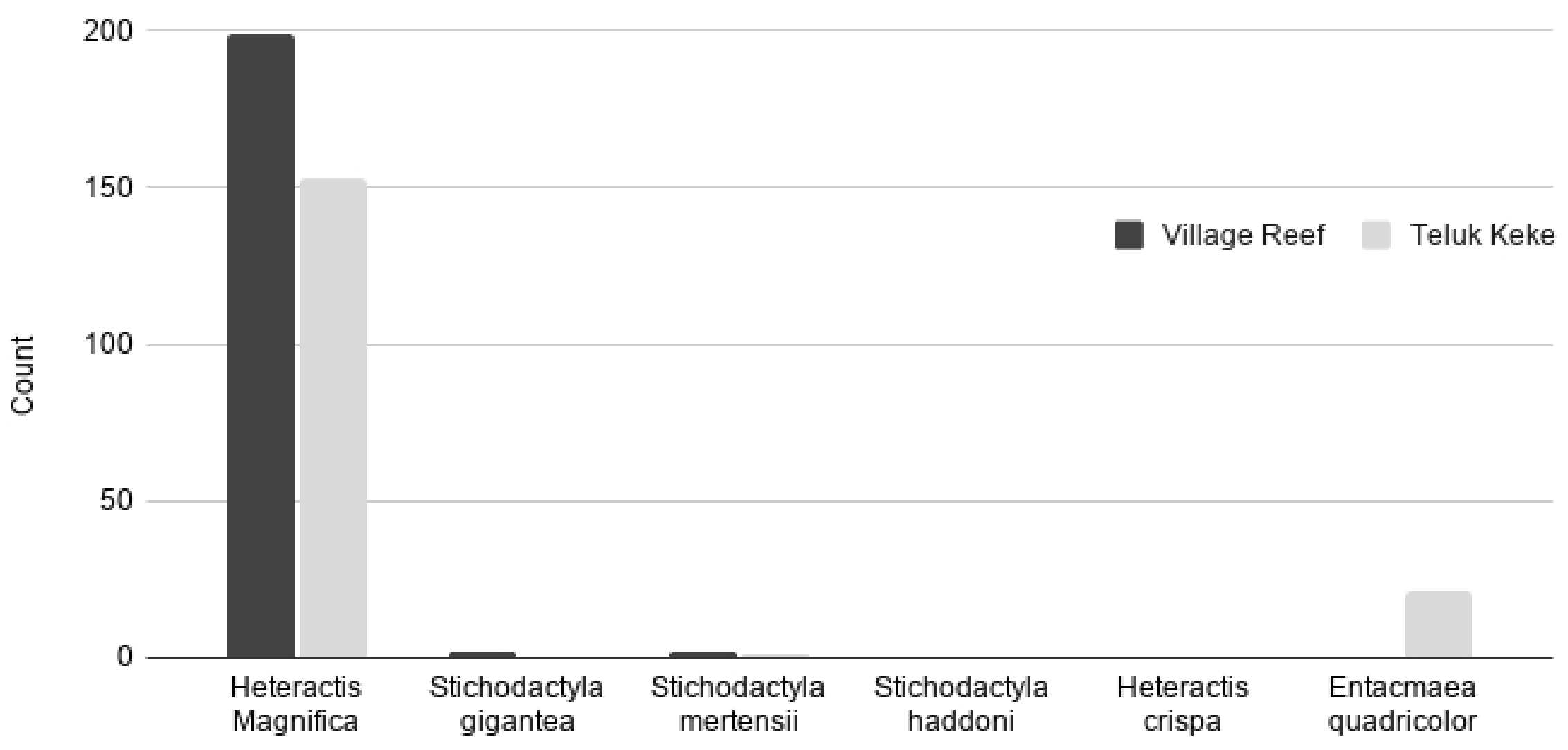

Sea Anemone Species

Figure 2. Bar graph displaying sea anemone spec 


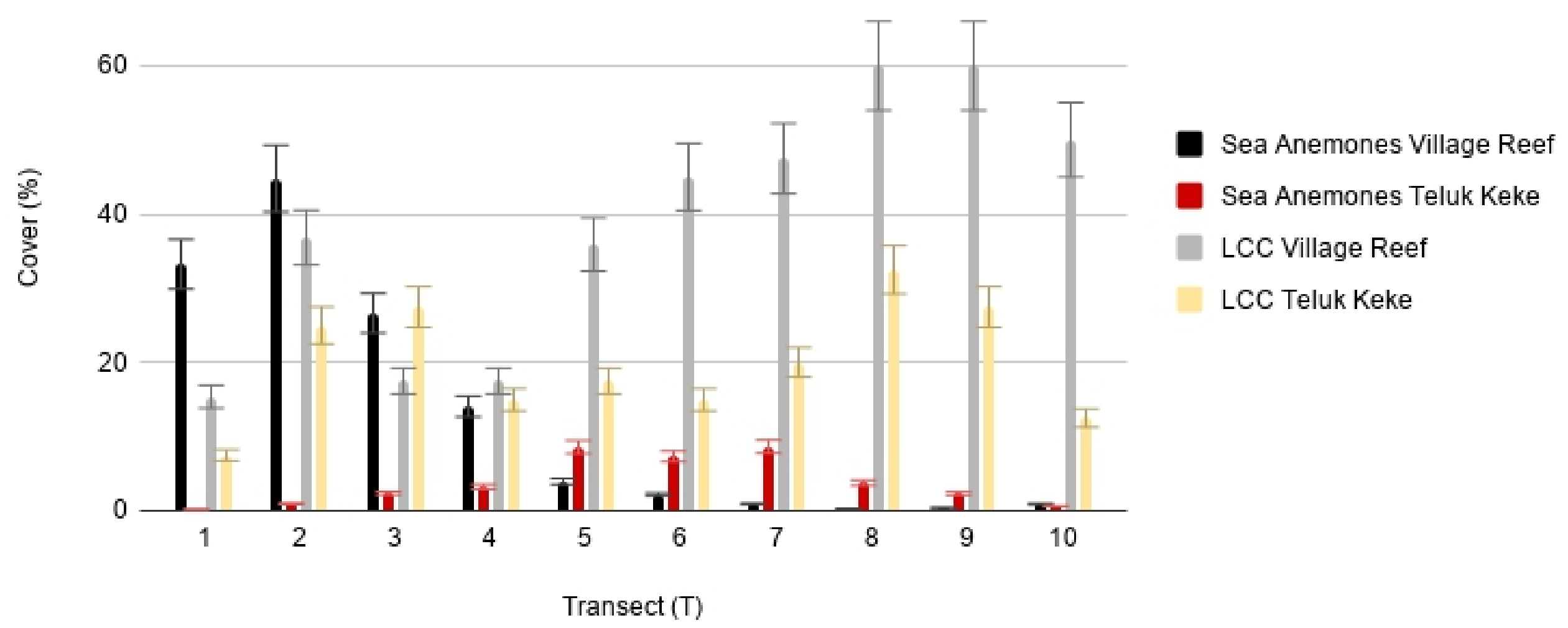

Figure 3. Bar graph displaying sea anemone cover anc 


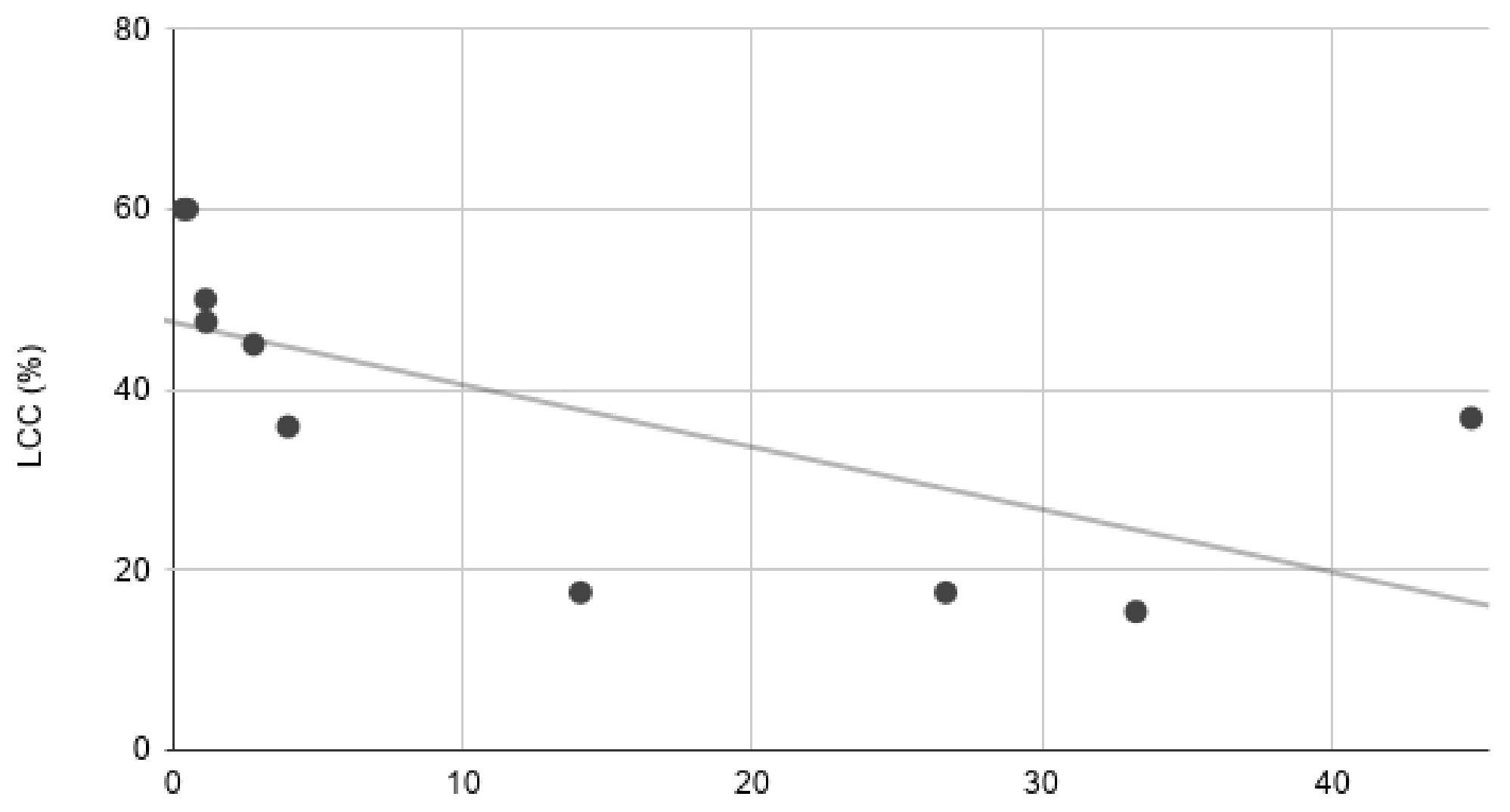

Sea Anemone Cover (\%)

Figure 4. Scatterplot displaying the relation 